\title{
Heavy metal content of vegetables irrigated with mixtures of wastewater and sewage sludge in Zimbabwe: implications for human health
}

\author{
Muchuweti, M., ${ }^{1}$ Birkett, J.W., ${ }^{2}$ Chinyanga, E., ${ }^{1}$ Zvauya, R., ${ }^{1}$ Scrimshaw, M.D ${ }^{3}$. and Lester, J.N. ${ }^{3 *}$ \\ ${ }^{1}$ Department of Biochemistry, University of Zimbabwe, M.P. 167, Mount Pleasant, Harare, Zimbabwe \\ ${ }^{2}$ School of Biomedical and Natural Sciences Nottingham Trent University, Clifton Campus, Nottingham,
} NG11 8NS, UK

${ }^{3}$ Department of Environmental Science and Technology, Imperial College London, Faculty of Life Sciences, London, SW7 2AZ, UK

\begin{abstract}
There is growing public concern in Zimbabwe over the illegal cultivation of vegetables on soils amended with sewage sludge or irrigated with admixtures of sewage and sewage sludge. Excessive accumulation of heavy metals in agricultural soils may not only result in environmental contamination, but lead to elevated heavy metal uptake by crops, which may affect food quality and safety. The work reported here studied heavy metal concentrations in crops irrigated with sewage sludge and sewage/sewage sludge admixtures at Firle Municipal Farm in Harare. The crops analysed in this study are heavily contaminated with the four regulated elements $\mathrm{Cd}, \mathrm{Cu}, \mathrm{Pb}$ and $\mathrm{Zn}$. This contamination is at its highest in two of the staple dietary crops maize and tsunga. Tsunga leaves contained $3.68 \mathrm{mg} \mathrm{kg}^{-1} \mathrm{Cd}$, over 18 times the permissible level by the EU standards $\left(0.2 \mathrm{mg} \mathrm{kg}^{-1}\right)$; $\mathrm{Cu}$ concentrations were $111 \mathrm{mg} \mathrm{kg}^{-1}, 5$ times the EU Standard $\left(20 \mathrm{mg} \mathrm{kg}^{-1}\right)$; concentrations of $\mathrm{Pb}$ were $6.77 \mathrm{mg} \mathrm{kg}^{-1}$, over 22 times the permissible levels allowed by both EU standards and UK guidelines $\left(0.3 \mathrm{mg} \mathrm{kg}^{-1}\right)$; Zn concentrations were $221 \mathrm{mg} \mathrm{kg}^{-1}$, over 4 times the guideline value (50 $\mathrm{mg} \mathrm{kg}^{-1}$ ). The other plants (beans, maize, peppers and sugarcane) also contained concentrations of heavy metals above the permissible levels. Furthermore the concentrations observed in this study were higher than those reported by other workers who have examined vegetation from other contaminated sites. This study highlights the potential risks involved in the cultivation and consumption of vegetables on plots irrigated with sewage sludge, a practice which may place at risk the health of the urban population who consume these vegetables.
\end{abstract}

Keywords: Soils; Sewage sludge; Wastewater; Heavy metals; Green vegetables, Zimbabwe

* Corresponding author. Tel +44 (0)20 7594 6014; fax +44 (0)20 75946016

e-mail j.lester@imperial.ac.uk 


\section{Introduction}

A number of factors influence the concentration of heavy metals on and within plants. These factors include climate, atmospheric deposition, the nature of the soil on which the plant is grown and the degree of maturity of the plant at the time of harvesting, (Scott et al., 1996; Voutsa et al., 1996; Lake et al., 1984). The nature of the soil is one of the most important factors in determining the heavy metal content of food plants (Itanna, 2002; Madyiwa et al., 2002a). However the heavy metal content in plants can also be affected by other factors such as the application of fertilisers, sewage sludge or irrigation with wastewater (Devkota and Schmidt, 2000; Frost and Ketchum, 2000; Mangwayana, 1995). Heavy metal contamination of agricultural soils can pose long-term environmental problems and is not without health implications (Sauve et al., 1996; Ferguson, 1990; Chumbley, 1982). When the metals are derived from anthropogenic sources, this can strongly influence their speciation and hence bioavailability as is the case when metal contaminated sewage sludge is applied to agricultural land (Lester, 1987).

The Pension Farm (Harare, Zimbabwe) was established in 1952 in order to provide a disposal route for sewage sludge and wastewater from the nearby Firle Wastewater Treatment Works (FWTW). The farm is situated $15 \mathrm{~km}$ from the city centre and is located near the Mukuvisi River and Lake Chivero, the major source of drinking water for the city of Harare (Nhapi et al., 2001). In 1972 the City Council began growing maize and beans on the farm as the soil was rich in nutrients derived from the sewage sludge and wastewater. Food crop cultivation on the farm was abandoned in 1976 after concerns about the safety of such crops were expressed. Nyamangara and Mzezewa (1999), have reported the concentrations of heavy metals in the soils and grass from Pension Farm, which is utilised by the City Council to graze a herd of cattle, with the beef produced entering the public food supply. 
The FWTW is one of the largest treatment plants that serve the City of Harare, with influent to the works consisting of both industrial and domestic wastewaters. The treatment plant comprises six units with a capacity to process $144 \times 10^{6} \mathrm{~L}$ per day. Two of the units use trickling filters and produce $48 \times 10^{6} \mathrm{~L}$ of low quality effluent per day (suspended solids $50 \mathrm{mg}^{-1}$, Biochemical Oxygen Demand $40 \mathrm{mg} \mathrm{l}^{-1}$ ) which is used for irrigation of the farm grazing land. The other four units are activated sludge biological nutrient removal plants that produce $96 \times 10^{6} \mathrm{~L}$ of high quality effluent per day (Suspended Solids 20 $\mathrm{mg} \mathrm{l}^{-1}$, Biochemical Oxygen Demand $10 \mathrm{mgl}^{-1}$, phosphorus $1 \mathrm{mg}^{-1}$ as $\mathrm{P}$ ) which is discharged directly to the receiving water. The low quality effluent produced by the trickling filters is mixed with digested sewage sludge from all the unit treatment processes to produce a slurry (3-4\% solids) which is subsequently used for irrigating 860 ha of grazing land at Pension Farm (Madyiwa et al., 2002b).

Flood irrigation of pastures has been practised for 30 years at Pension Farm as a form of tertiary treatment of sewage effluent, utilising soil microorganisms to complete the treatment process. The cultivation of crops on the farm by workers using wastewater for irrigation raises concerns about the safety of such vegetables with respect to their heavy metal content. The farm workers divert wastewater and the mixture of sewage sludge and wastewater from the flood irrigation channels by creating trenches to direct the flow to their crops. The vegetables produced are consumed by the villagers, largely supplying their entire dietary requirement This study was therefore initiated to assess the concentrations of heavy metals in soils and plants grown on these plots. Of particular interest were the leaves and stems of the tsunga plant (Brassica juncea) which are grown in large quantities during the dry season and are frequently their only source of fresh vegetable during this period (May - September).

\section{Materials and methods}

\subsection{Study site and soils}


The average annual precipitation (over the past 30 years) for the area is $820 \mathrm{~mm}$ (Department of Meteorological Services., 1977) with most received as high intensity storms in summer (October April). The study site comprised two adjacent sections with identical parent soil one on Churu Farm (control) and the other on Firle Farm (sewage sludge amended). Churu farm, which has not been subjected to wastewater disposal, is located less than 1 kilometre away from the FWTW.

The experimental site was situated on predominantly granitic sandy soil classified as Haplic Arenosol. The soil consisted of sandy top layer $(0-30 \mathrm{~cm})$ overlying sandy loam subsoil (30-50 $\mathrm{cm})$. The soils were acidic $\mathrm{pH} 4.6 \pm 0.3$ with the sewage sludge and effluent irrigated soils being on average $1 \mathrm{pH}$ unit higher. The soils had very low CEC $(1.4 \pm 0.2 \mathrm{meq} / 100 \mathrm{~g})$ and organic C content $(1.4 \% \pm 0.2 \%)$, consistent with sandy soils. However addition of sewage sludge and effluent resulted in a 20 fold increase in the CEC and a two fold increase in the organic content of 0-20-cm soil layer which is consistent with other observations at this site (Madyiwa et al., 2002a).

\subsection{Sampling and sample preparation}

Sampling of the control soils at Churu farm was undertaken over a 50 x 200m plot. Sampling at Firle Farm was carried out in 3 adjacent plots: A, B, C (50 x 50m). Each plot was essentially cultivated as a monoculture, typically maize, sugarcane or tsunga, with other species usually only grown in very small quantities. Although there were approximately thirty actively cultivated plots in this community all being irrigated with sludge/effluent, because this practice was strictly against the instructions of their employers only three of the growers were willing to collaborate in the study. Moreover, given the limited quantities of some crops cultivated they would only agree to sampling when these yielded in abundance, this applied to beans, peppers and tomatoes. As a result of this, the quantities of crops obtained to generate the sample numbers required to permit the use of statistical analysis were not possible. 
Sampling of soils was undertaken using a $25 \mathrm{~mm}$ diameter stainless steel tube which was pushed to the required depth when the tube had been removed from the soil, the core was extruded from the corer with the aid of a stainless steel rod. Five points where the surface was free of plant material and debris were selected for soil sampling on each plot. Samples were placed in plastic bags and sealed for transport and storage. Samples were taken from three depths of 0- $20 \mathrm{~cm}$ for topsoil, 20$35 \mathrm{~cm}$ for the middle horizon and $35-50 \mathrm{~cm}$ for sub-soil. In the laboratory the samples were airdried and sieved using a 2-mm mesh stainless steel sieve. Following this the samples were dried in an oven (Gruenthal and Bekker, Harare) at $105^{\circ} \mathrm{C}$ overnight (at least $12 \mathrm{~h}$ until constant weight was achieved) and then reduced to powder using a S.100A Siebtechnik pulveriser (manufactured by Labor-Scheibenschingmuhle Gmbb, Germany).

Various crops were also harvested from near the points where soils were taken in each plot at Firle farm. The following vegetation was sampled: tsunga (Brassica juncea), tomato (Lycopersicon esculentum), bean (Vicia faba), maize (Zea mays), sugar cane (Saccharum officinarum) and pepper (Capsium annum). The crops were taken to the laboratory within one hour of harvesting and washed as would be done during normal food preparation to remove any surface deposits. They were separated into edible and non-edible parts and composite samples formed for each species. The plants were then dried as stated above and treated in the same way as the soils.

\subsection{Analysis}

The samples were digested using aqua regia ( $\left.\mathrm{HCl}: \mathrm{HNO}_{3}, 3: 1 \mathrm{v} / \mathrm{v}\right)$ (USEPA, 2001a). Soil samples (2.0g) were accurately weighed in polyvinyl containers and aqua regia $(8 \mathrm{ml})$ added. The containers were capped, transferred to a carousel and then left for $20 \mathrm{~min}$, the carousel with the samples was then placed in a microwave digester and irradiated at for 30 min (MLS 1200 MEG, Laboratory System GMbH, Germany). Samples were then filtered through whatman GF/C filter papers in borosilicate funnels into $50 \mathrm{ml}$ borosilicate volumetric flasks and made up to the mark with distilled 
water. Solutions were then analysed for heavy metals using Perkin Elmer Analyst 800 atomic absorption spectrophotometer (Perkin Elmer, Harare).

Plant samples $(0.5-1.0 \mathrm{~g})$ were accurately weighed in polyvinyl containers followed by the addition of nitric acid (3.3ml), hydrogen peroxide $(1.7 \mathrm{ml})$ and water $(1 \mathrm{ml})$ (USEPA, 2001b). The plant material was then treated in the same way as the soil samples.

\section{Results and Discussion}

\subsection{Concentration of Heavy Metals in Soils}

Data for the seven heavy metals in the three experimental soil plots and for soil at the control site are presented in Figure 1. To facilitate evaluation and comparison two values have been superimposed on each figure. A background value, for chromium, copper, mercury, nickel, lead and zinc taken from Downs et al. (1999), and cadmium from Lake (1987). In addition, the value for the "maximum permissible concentration of potential toxic elements (PTE) after biosolids application", has also been applied to the data derived from the European Union code of practice (EC, 2001) and United Kingdom Regulations (1989), the values used are those for soil with a pH in the range of 5 to 5.5 typical of those in this study. These guidelines have been produced specifically to protect food quality as well as the environment (Lester and Edge, 2001).

It is readily apparent that only the concentrations of cadmium in the control soil exceeded background values, all the other metals exhibit values below background concentrations. However, it is evident that on all three-test plots that concentrations of all elements at all three depths examined were considerably above background values (Figure 1). The concentrations of cadmium, copper and zinc exceeded the PTE in sludge amended soils value at all three depths, whilst chromium, mercury and lead exhibited high surface enrichment $(0-20 \mathrm{~cm})$ which also substantially exceeded the PTE in sludge amended soil values. Nickel was the only element for which 
concentrations did not exceed the PTE in sludge amended soil values, being almost equal to this value in all three trial plots and exhibiting significant enrichment at all three depths.

\subsection{Concentration of Heavy Metals in crop plants}

Concentrations of heavy metals in both edible and non-edible portions of the crops are presented in Figure 2 and superimposed on the data for cadmium, copper, lead and zinc are the European Union Standards for these four elements in fresh vegetables (EC, 2001). No international standards or guidelines exist for chromium, mercury or nickel so background values for vegetation have been incorporated (Lake, 1987). It is apparent for cadmium, copper and lead that concentrations in all portions of these crops, both edible and non-edible, exceeded these standard limits in fresh vegetables. In the case of zinc all the edible portions of the crops again substantially exceeded the regulatory value, only some of the non-edible portions, such as bean root and the leaves of maize, beans and sugarcane fell below that value. Values for chromium were significantly above the background value, whilst those of mercury and nickel were just within or slightly above the background values.

The data from this study indicates that the crops analysed in this study are heavily contaminated with the four regulated elements cadmium, copper, lead and zinc. Moreover, this contamination is at its highest in two of the staple dietary crops maize and tsunga. For most of the plants the concentrations heavy metals present were above permissible levels (see Figure 2). Of the edible portions tsunga appeared to bioaccumulate the highest concentrations of heavy metals. Cadmium levels in tsunga were eighteen times more than the permissible level. In comparison with data for other Brassicas, the level of cadmium was five times above the value reported for spinach by Sherlock (1986), and approximately fifty times the value reported by Itanna (2002) for Swiss Chard. In green beans cadmium was three times more than previous values reported (Rethman and Truter, 2001). The concentrations of copper were relatively high in this study when compared to those 
obtained by other workers, with tsunga having the highest, approximately eighty six times more than the value reported for leafy vegetables $\left(1.3 \mathrm{mg} \mathrm{kg}^{-1} \mathrm{Cu}\right)$ by Sanchez-Castillo et al. (1998). The levels of chromium in tsunga leaves were about eight times greater than those values for the similar Swiss Chard vegetable (2.05 $\mathrm{mg} \mathrm{kg}^{-1} \mathrm{Cr}$ ) (Itanna, 2002). Itanna (2002) also observed concentrations of lead in Swiss Chard $\left(1.79 \mathrm{mg} \mathrm{kg}^{-1} \mathrm{~Pb}\right)$ which are three times lower than the values recorded in tsunga leaves in the present study. Most plants did not appear to bioaccumulate nickel. The values for zinc were much higher for all plants in the present study than those reported by other workers. The results from the study demonstrate that tsunga readily bioaccumulates heavy metals.

\section{Conclusions}

The tsunga vegetable is consumed by the urban population of the city of Harare thus exposing the population to dangerous levels of heavy metals. The results presented demonstrate that there is a risk associated with consumption of vegetables grown on these plots, with the vegetable still looking apparently healthy and growing well despite accumulating heavy metals to concentrations which substantially exceed maximum values considered safe for human consumption.

\section{Acknowledgements}

The authors wish to thank the British Council for financial support and the University of Zimbabwe for supporting other aspects of the work.

\section{References}

Chumbley, C.G., 1982. Cadmium and lead content of vegetable crop grown on land with a history of sewage sludge application. Environ. Pollut. 4, 231-237

Department of Metrological Services, 1977. Mean Rainfall in Rhodesia. Rainfall Handbook Supplement No. 8, 62 pp.

Downs, S.G., Macleod, C.L., Jarvis, K., Birkett, J.W., Lester, J.N., 1999. Comparison of mercury bioaccumulation in eel (Aquilla aquilla) and roach (Rutilus rutilus) from river systems in East 
Anglia, UK. II. Sources of mercury to fish and the role of atmospheric deposition. Environ. Technol. 20, 1202-1212.

Devkota, B., Schmidt G.H., 2000. Accumulation of heavy metals in food plants and grasshoppers from the Taigetos Mountains, Greece. Agric. Ecosyst. Environ. 78, 85-91.

EC, 2001. Commission Regulation (EC) 466/2001. Setting maximum levels for certain contaminants in foodstuffs. Official Journal of the European Communities, pp77.

Ferguson E. J. 1990. Heavy metals in plants. In:Ferguson (Ed) The heavy elements, Chemistry, Environmental Impact and Health Effects. Pergamon Press, Oxford, UK, pp7-30

Frost, H.L., Ketchum, L.H., 2000. Trace metal concentration in durum wheat from application of sewage sludge and commercial fertilizer. Adv. Environ. Res. 4, 347-355.

Itanna, F., 2002. Metals in leafy vegetables grown in Addis Ababa and toxicological implications. Ethiopian. J. Health Develop. 6, 295-302

Lake, D.L., Kirk, P.W.W. and Lester, J.N., 1984. The fractionation, characterisation and speciation of heavy metals in sewage sludge and sewage sludge amended soils: a review J. Environ. Qual., 13, 175-183.

Lake, D.L., 1987. Chemical speciation of Heavy Metals in Sewage Sludge and Related Matrices. In: Lester, J.N., 1987. Biological Treatment. In: Lester, J.N. (Ed.), Heavy Metals in Wastewater and Sludge Treatment Process. CRC Press Inc., Boca Raton, USA, pp15-40.

Lester, J.N., Edge, D., 2001. Sewage and sewage and sewage sludge treatment. In: Harrison, R.M. (Ed), Pollution causes, effects and control. Royal Society of Chemistry, London, pp113-144.

Madyiwa, S., Chimbari, M., Nyamangara, J., Bangira, C., 2002a. Cumulative effects of sewage sludge and effluent mixture application on soil properties of a sandy soil under a mixture of star and kikuyu grasses in Zimbabwe. Phys. and Chem. Earth, Parts A/B/C 27, 747-753.

Madyiwa, S., Chimbari, M., Nyamangara, J., Bangira, C., 2002b. Phyto-extraction capacity of Coynodon lemfuensis (Star Grass) at artificially elevated concetrations of $\mathrm{Pb}$ and $\mathrm{Cd}$ in sandy soils under greenhouse conditions. $3^{\text {rd }}$ WaterNet/Warfsa Symposium 'Water Demand Management for suitable Development', Dar-es-Salaam, pp 1-10.

Mangwayana, E.S., 1995. Heavy metals pollution from sewage sludge and effluent of soil and grasses at Crowborough Farm, B.Sc. Thesis, University of Zimbabwe, pp 63.

Nhapi, I., Hoko, Z., Siebel, A., Gijzen, H.J., 2001. Assessment of the major water and nutrient flows in the Chivero catchment area, Zimbabwe. Phys. Chem. Earth, Parts A/B/C 27, 783-792. 
Nyamangara, J., Mzezewa, J., 1999. The effect of long term sewage sludge application on Zn, Cu, $\mathrm{Ni}$ and $\mathrm{Pb}$ levels in a clay loam soil under pasture grass in Zimbabwe. Agric. Ecosyst.Environ. 73, 199-204.

Rethman, N.F.G., Truter, W.F., 2001. Plant responses on soils ameliorated with waste products. 18th National meeting of ASSMR. Albuquerque, New Mexico. U.S.A. pp425.

Sanchez-Castillo, C.P., Dewery, P.J.S., Aguirre, A, Lara, J.J., Vaca, R., Ortiz, M., Escamilla, I., James, W.P.T., 1998. The mineral content of Mexican fruits and vegetables. J. Food Comp. Anal. $11,340-356$.

Sauve, S., Cook, N., Hendershot, H.W., McBridge, B.M., 1996. Linking tissue copper concentrations and soil copper pools in urban contaminated soils. Environ. Pollut. 94, 153-157.

Scott, D., Keoghan, J.M., Allan, B.E., 1996. Native and low-input grasses--a New Zealand high country perspective. New Zealand J. Agric. Res. 39, 499-512.

Sherlock, J., 1986. Cadmium in foods and diet. In: Cadmium in the Environment. Experientia Supplementum 50; pp 110.

USEPA, 2001a. Microwave assisted digestion of sediments, sludges, soils and oils. Official Methods/ US EPA methods: Method 3051a, pp846.

USEPA, 2001b. Microwave assisted acid digestion of siliceous materials. Official Methods/ US EPA methods: Method 3051, pp846.

United Kingdom Regulations, 1989. Statutory Instrument 1989 No. 1263 Sludge (Use in Agriculture) Regulations. MAFF, HMSO, London, pp15-27

Voutsa, D., Grimanis, A., Samara C., 1996. Trace elements in vegetables grown in an industrial area in relation to soil and air particulate matter. Environ. Pollut. 94, 325-335. 